\title{
Analyses of Governance Indicators Affecting Flow of Foreign Aid: An ARDL Approach
}

\author{
KHAWAJA ASIF MEHMOOD \\ Assistant Professor, School of Economics, \\ Bahauddin Zakariya University, Multan, Pakistan. \\ Email: khawjaasif@bzu.edu.pk
}

\author{
ALI AZAM \\ Assistant Professor, Department of Economics, \\ The Islamia University of Bahawalpur, Bahawalpur, Pakistan. \\ Email: aliazammalik@yahoo.com \\ RABIA HAFEEZ \\ MPhil Scholar, School of Economics, \\ Bahauddin Zakariya University, Multan, Pakistan \\ Email: rabiahafeez828@gmail.com
}

\begin{abstract}
One of the important components of foreign capital is foreign aid that helps to address macroeconomic issues of recipient country. Macroeconomic disorders such as poverty and unemployment are tackled through foreign aid. Need of time is to evaluated the factors that affect the flow of foreign aid. Data of study was gathered from 1980 to 2019. Findings of study confirmed negative relationship of control of corruption on foreign aid. Likewise, negative relationship was found with political stability and government effectiveness with foreign aid. As a policy implication, government is to focus on settling down internal unrest on account of such governance indictors. It is so to gain more benefit from the same to overcome macroeconomic disorders.
\end{abstract}

Keywords: Foreign Aid, Political Stability, Control of Corruption, Government Effectiveness.

\section{Introduction}

Foreign aid facilitates developing countries in achieving macroeconomic objectives which lack behind due to deficiency of capital. Foreign aid is given in form of loans and grant. However, the consequences of foreign aid have to be bearded by the recipient. Those consequences are in form of interferences into the domestic policies and government formations which ultimately benefit those who remit these foreign inflows into the accounts of developing nations. Therefore, as a matter of truth, even tremendous amount of aid still fail to enable developing nations to achieve economic stability. Moreover, improvements in their education, state of capital, living conditions, and infrastructure are also found absent. The third world countries have understood the value of this aid and the advantages they can achieve from this financial aid, they still have not realized the extent of the effects of this aid in form of negative externalities. Foreign aid and its mechanism of usage must be distinguished so that proper dispense of capital be made.

Limited foreign trade is a reason for depending upon foreign aid (Bauer, 1972, Bandow, 1987). Foreign trade is treated as a supplement for the developing countries to replace foreign aid. However, due to poor technology and minimal private investment, developing countries such as Pakistan fail to fulfil needs of 
capital. Therefore, such countries are bound to rely upon foreign aid for tackling macroeconomic issues those are held freeze due to deficiency of capital.

Pakistan is relying upon foreign aid and loans since 1958. In recent, Pakistan is struggling to raise money for settling import bills and outstanding. For the year 2017-2018, Pakistan accepted $\$ 8.09$ billion of foreign aid. This does not include $\$ 3.72$ billion of foreign aid in the form of assistance from the foreign banks which is about $\$ 3.716$ billion. For fiscal year 2018-2019, Pakistan has received $\$ 129.29$ million of foreign aid along with $\$ 60.54$ million of loans or debts and grant of $\$ 68.74$ million.

Pakistan has faced numerous problems which are the main reason of hindrance in achieving economic and developmental goals. Pakistan faces issue of governance like that of corruption as found in major or minor democratic or non-democratic institutions of developing world. Moreover, weak functioning of democratic institutions is a cause of rapidly increasing number of unemployed. Moreover, unequal distribution of wealth increases the deprivation of areas and regions such as interior part of Sindh, Baluchistan, Southern Punjab, and the ignorance in the proper development of these areas whose consequences are shared by the poor people to then experience and suffer (Haider, 2018).

Foreign aid being important content in addressing socioeconomic issues requires focus on its determinants. The main idea to contemplate is; what the effects of governance indicators on foreign aid are? The study is organized in 5 Sections. In this respect, introduction is rendered in Section I. Whereas, Section II and III are allocated for literature review and methodology. Likewise, results and discussion and conclusion and policy implications are given in Section IV and V, respectively.

\section{Literature Review}

\section{Types of Foreign Aid}

Foreign aid is present in many forms. The most vastly known forms are;

\section{Bilateral Aid}

Bilateral aid is government to government transfer. Economists view it as part of a well-designed strategy to improve their standard of living and provide the standard HDI. Maizels and Nissanke (1984) suggested bilateral foreign aid targets interests of donors in first place. While there were certain factors that were definitely found on each of the both kinds of aids.

\section{Multilateral Aid}

Multilateral aid is the donations from many donors. Under multilateral aid, funds are pooled into international organisations like; World Bank, United Nations (UN), and the International Monetary Funds. UN uses these funds to address political or social unrest in the developing world.

\section{Tied Aid}

Tied aid is granted to third world on certain conditions. The donor country demands that the developing country to spend tied aid on donors' products or areas as demanded by this aid.

\section{Project Aid}

There is a positive externality related to project aid. It is somehow a direct investment in a poor country. It is not subject to corruption and poor policies. That is the reason public enjoys the spell outs of project which are in-positive and therefore experience to have fruitful effects in living standards. 


\section{Voluntary Aid}

This aid is for purpose of development and for the alleviation of poverty. Being true form of charitable aid, no return of principal amount and interest rate is demanded in reversal of the said pledges.

Researchers are conducted to locate foreign aid useful. Within the past literature, foreign aid is located as a determinant of economic growth. Levine and Renelt (1992) and Barro and Sala-i-Martin (1997) suggested that investment does not promise to bring growth. But the right kind of policies as well as social and political structure treated to be the main determinants for effective investment (Hall \& Jones,1999; Fafchamps, 2000).

The economy of a nation is mostly driven by the right kind of private investment made. The investment that is public helps in the forming and establishing of the infrastructure of the country, what necessary requirements are needed for it. Foreign aid is closely linked to investment. The constraints linked with investment can simply be removed by foreign aid (Bacha, 1990).

Chenery and Strout (1966) advocated that when government authorities have faulty knowledge about investments and foreign aid, they have a hard time to find productive measures for development and growth in economy. Proper use of foreign aid show positive correlation with growth as well as investment (Hjertholm \& White, 2000). Findings of Gomanee et al. (2005) showed foreign aid to minute but positively influence economic growth in the Sub-Saharan regions of Africa. According to Elbadawi (1999), foreign aid had mixed effects in context of appreciation of the exchange rate. It is so because findings found economic growth to lessen because currency appreciation adversely affected the rate of exports. To Mehmood et al., (2020), such a drastic exchange rate wavers affect private investment. Therefore, proper allocation of foreign aid, political and institutional prevalence, and existence of property rights are prerequisites for gain of efficiencies (Morgenthau, 1962; Weck-Hannemann \& Schneider, 1988)

Rowley, 1998 exclaimed that the state government of developing nations rely on foreign aid along with poor policies by the time of funds' allocation. According to Svensson (2000), foreign aid is believed to solve entire state problems. Being wrong in thinking, such nations remain poor rather get worst. Corruption at state level and foreign aid bear positive relationship. Laffont and Guessan (1999) discussed that increase in the foreign aid further increases the element of state owned corruption which ultimately affect the trade. In this context, Friedman (1958) identified the negative aspect of the foreign aid. Foreign aid takes away investment funds away from private sector thus strengthens public sectors due to more funds in-hands.

Much of the research is seen to be inconclusive to confirm whether foreign aid is beneficial to growth, developed, and other economic problems such as poverty (Kosack \& Tobin, 2006; Minoiu et al., 2010; Alvi and Senbeta, 2011; Rajan \& Subramanian, 2008). Meanwhile, economist also exclaimed that unless accompanied with proper policies, macroeconomic reward of foreign aid is held veiled. It is due to the selfinterests of donors and far away the motive to address the actual problems of the recipient (Little, 1979, Maizels \& Nissanke, 1984)

To Lake (1999) and Nelson (2010), much of the influence is posted on whether foreign aid is to be multilateral of bilateral in nature. However, the contradictions still persist as to know the effectiveness of foreign aid in the presence of given status of governance. In this context, Minoiu and Reddy (2010) came up with the point that bilateral aid is welcomed when there are political motive of the both governments. On the other side, multilateral aid is determined on good policies and ambitions of the country (Burnside and Dollar, 2000). Thus variations of the results are found when bilateral and multilateral aid is depended upon.

Studying of diverse variables which influence the allocation of foreign aid from the angle of donors is of utmost importance and in the interests of donor states. 


\section{Methodology}

Foreign aid is imperative since it facilitates to endorse conquering macroeconomic problems which are held unaddressed due to lack of capital. Moreover, issues such as terrorism, poverty and strengthening of institutions are also not away from the benefits of foreign aid which persisted due to corruption (Pallage \& Robe, 2015; Lawson \& Morgenstern, 2019).

\section{Data and Model Specification}

This study aims to scrutinize the outcome of determinants of foreign aid. Time period is selected from 1980 to 2019. The data were collected from Economic Survey of Pakistan, World Bank, and Bureau of Labour Statistics. To do so the analyses, following models are designed in the light of significance of foreign aid and its spell outs.

Model I

$$
F R A I D=\alpha_{0}+\alpha_{1} E G R+\alpha_{2} I N F+\alpha_{3} U E+\alpha_{4} P S+\alpha_{5} M 2+\varepsilon
$$

Where:

FRAID: Foreign Aid is measured as foreign assistance.

EGR: Economic Growth measured in terms of GDP

INF: Inflation measured as Consumer Price Index

UE: Unemployment

PS: Political Stability (measured as weak to strong at scale of -2.5 to 2.5 )

M2: Money Supply

$\epsilon$ : Error Term

Model II

$$
F R A I D=\alpha_{0}+\alpha_{1} E G R+\alpha_{2} C R P+\alpha_{3} I N F+\alpha_{4} T R+\alpha_{5} U E+\varepsilon
$$

Where:

CRP: Control of Corruption (measured as weak to strong at scale of -2.5 to 2.5)

TR: Trade Openness

Model III

$$
F R A I D=\alpha_{0}+\alpha_{1} E G R+\alpha_{2} I N F+\alpha_{3} U E+\alpha_{4} G E+\varepsilon
$$

Where:

GE: Governance (measured as weak to strong at scale of -2.5 to 2.5)

$\alpha_{0}$ is intercept in each model. $\alpha_{i}$ where $i=1,2, . ., 5$ are coefficient's slopes.

\section{Interpretation of Variables and Source of Data}

Foreign Aid (FAID): Official development assistance measured in million USD. 
Political Stability (PS): Ranges from -2.5 to 2.5 showing weak to strong political stability.

Control of Corruption (CRP): Ranges from -2.5 to 2.5 showing weak to strong control over corruption.

Government Effectiveness (GE): Ranges from -2.5 to 2.5 showing weak to strong effectiveness of government.

Economic Growth (EGR): GDP in million USD.

Inflation (INF): Consumer Price Index.

Trade Openness (TR): ratio of (Export + Import)/GDP $\times 100$.

Unemployment (UE): Rate of unemployment in percentage

Money Supply (M2): Includes cash money and saving deposits, money market securities, mutual funds, and other time deposits.

\section{Econometrics Analysis}

Following mandatory steps of regression analyses are gone through for the purpose of distinguishing effects of governance indicators of foreign aid.

\section{Test of Stationarity}

The time series data is checked for stationarity and the non-stationarity. For this purpose, Augmented Dickey Fuller Unit Root Test is used to check the stationarity and the non-stationarity of the data. The $\mathrm{H}_{0}$ shows that the time series is non-stationary which is opposite to the $\mathrm{H}_{1}$ (Dickey \& Fuller, 1979). In case of mixed results, Auto Regressive Distributed Lag (ARDL) technique is used.

\section{Bound Test}

Bound test is carried out for long run relationship (Azam et al., 2020). As depicted by Pesaran et al. (2001), computed F-statistics are checked against the upper bound critical values at I(1). If the computed Fstatistics are greater than upper bound critical values, cointegration exists otherwise not. The versions of bound test are written as follows:

$\mathrm{H}_{0}: \beta_{1}=\beta_{2}=\beta_{3}=\beta_{4}=\beta_{5}$

$\mathrm{H}_{1}: \beta_{1} \neq \beta_{2} \neq \beta_{3} \neq \beta_{4} \neq \beta_{5}$

Unrestricted Error Correction Models in respect of ARDL technique of coefficient estimation are given below:

Model-I

$$
\begin{aligned}
& \Delta F R A I D=\alpha+\beta_{1} F R A I D_{t-1}+\beta_{2} E G R_{t-1}+\beta_{3} I N F_{t-1}+\beta_{4} U E_{t-1}+\beta_{5} P S_{t-1}+ \\
& \beta_{6} M 2_{t-1}+\sum_{I=0}^{P_{1}} \delta_{1} \Delta F R A I D_{t-i}+\sum_{I=0}^{P_{2}} \delta_{2} \Delta E G R_{t-i}+\sum_{I=0}^{P_{2}} \delta_{3} \Delta I N F_{t-i}+ \\
& \sum_{I=0}^{P_{4}} \delta_{4} \Delta U E_{t-i}+\sum_{I=0}^{P_{5}} \delta_{5} \Delta P S_{t-i}+\sum_{I=0}^{P_{6}} \delta_{6} \Delta M 2_{t-i}+\varepsilon_{i}
\end{aligned}
$$

Model-II

$$
\begin{aligned}
& \Delta F R A I D=\alpha+\beta_{1} F R A I D_{t-1}+\beta_{2} E G R_{t-1}+\beta_{3} C R P_{t-1}+\beta_{4} I N F_{t-1}+\beta_{5} T R_{t-1}+ \\
& \beta_{6} U E_{t-1}+\sum_{I=0}^{P_{1}} \delta_{1} \Delta F R A I D_{t-i}+\sum_{I=0}^{P_{2}} \delta_{2} \Delta E G R_{t-i}+\sum_{I=0}^{P_{2}} \delta_{3} \Delta C R P_{t-i}+ \\
& \sum_{I=0}^{P_{4}} \delta_{4} \Delta I N F_{t-i}+\sum_{I=0}^{P_{5}} \delta_{5} \Delta T R_{t-i}+\sum_{I=0}^{P_{6}} \delta_{6} \Delta U E_{t-i}+\varepsilon_{i}
\end{aligned}
$$


Model-III

$$
\begin{aligned}
& \Delta F R A I D=\alpha+\beta_{1} F R A I D_{t-1}+\beta_{2} E G R_{t-1}+\beta_{3} I N F_{t-1}+\beta_{4} U E_{t-1}+\beta_{5} G E_{t-1}+ \\
& \sum_{I=0}^{P_{1}} \delta_{1} \Delta F R A I D_{t-i}+\sum_{I=0}^{P_{2}} \delta_{2} \Delta E G R_{t-i}+\sum_{I=0}^{P_{2}} \delta_{3} \Delta I N F_{t-i}+\sum_{I=0}^{P_{4}} \delta_{4} \Delta U E_{t-i}+\sum_{I=0}^{P_{5}} \delta_{5} \Delta G E_{t-i}+\varepsilon_{i}
\end{aligned}
$$

\section{Results and Discussion}

This section is devoted to publish the analytical results on descriptive statistics and regression. Importantly, the empirical evaluation of the governance indicators and their affects on foreign aid in Pakistan are given below.

Table 1 shows the results of descriptive statistics. The mean value of FAID is 0.93. Standard deviation is 0.67. The values represent 39 percent of the deviation from mean value. PS, CRP, and GE are having mean values of $-1.31,-1.00$, and -0.50 respectively. Among these governance indicators, GE is showing wider dispersion from mean value. Similarly, INF, M2, and TR also exhibit significant deviation from mean value. However, about 70 percent of the deviation is recorded on UE. Other than PS, TR, and GE, variable of the study are positively skewed. A distribution that is more peaked and has fatter tails than normal distribution has kurtosis value greater than 3 (the higher kurtosis, the more peaked and fatter tails. According to the results, FAID and INF are leptokurtic. Rest of regressors are platykurtic. Jarque Bera results confirm normal distribution except FAID and TR.

Table 1: Descriptive Statistics Results

\begin{tabular}{|llllllllll|}
\hline & FRAID & PS & CRP & GE & EGR & INF & TR & UE & M2 \\
\hline Mean & 0.93 & -1.31 & -1.00 & -0.50 & 6487.85 & 8.08 & 33.39 & 2.93 & 42.33 \\
Std. Dev. & 0.67 & 1.00 & 0.14 & 0.16 & 3041.09 & 3.87 & 3.34 & 1.72 & 3.46 \\
Skewness & 1.21 & -0.01 & 0.83 & -0.58 & 0.47 & 0.74 & -0.61 & 0.70 & 0.27 \\
Kurtosis & 3.71 & 1.68 & 2.78 & 2.16 & 2.16 & 3.69 & 2.98 & 2.31 & 1.99 \\
Jarque-Bera & 10.28 & $2.83 *$ & $4.60^{*}$ & $3.34 *$ & $2.61 *$ & $4.39 *$ & 2.49 & $3.98^{*}$ & $2.13 *$ \\
\hline
\end{tabular}

It is essential to check the state of stationarity before any regression analysis is run. In this regard, Table 2 is given to show the outcomes of ADF test of stationarity. The findings conclude that none of the variable is integrated of $\mathrm{I}(2)$. The conclusion drawn is that; mixed order of integration i.e. $\mathrm{I}(1)$ and $\mathrm{I}(0)$ are found. Such findings suggest ARDL to be appropriate for the regression analyses.

\begin{tabular}{|c|c|c|c|c|c|c|c|}
\hline \multirow[t]{2}{*}{ Variables } & \multicolumn{3}{|c|}{ Level } & \multicolumn{3}{|c|}{ 1st difference } & \multirow[b]{2}{*}{ Conclusion } \\
\hline & None & Constant & $\begin{array}{l}\text { Constant \& } \\
\text { Trend }\end{array}$ & None & Constant & $\begin{array}{l}\text { Constant \& } \\
\text { Trend }\end{array}$ & \\
\hline FRAID & 0.47 & 0.44 & 0.25 & 0.00 & 0.00 & 0.0003 & $\mathrm{I}(1)$ \\
\hline PS & 0.76 & 0.51 & 0.91 & 0.004 & 0.02 & 0.04 & $\mathrm{I}(1)$ \\
\hline CRP & 0.25 & 0.50 & 0.18 & 0.00 & 0.00 & 0.0001 & $\mathrm{I}(1)$ \\
\hline GE & 0.05 & 0.42 & 0.01 & -- & -- & -- & $\mathrm{I}(0)$ \\
\hline EGR & 1.00 & 1.00 & 1.00 & 0.06 & 0.05 & 0.26 & $\mathrm{I}(1)$ \\
\hline INF & 0.14 & 0.07 & 0.22 & -- & -- & -- & $\mathrm{I}(0)$ \\
\hline UE & 0.92 & 0.88 & 0.45 & 0.00 & 0.0001 & 0.0006 & $\mathrm{I}(1)$ \\
\hline M2 & 0.62 & 0.10 & 0.27 & -- & -- & -- & $\mathrm{I}(0)$ \\
\hline TR & -- & -2.94 & -3.53 & -- & -2.94 & -3.53 & $\mathrm{I}(1)$ \\
\hline
\end{tabular}

Table 2: Unit Root Results 
For the cointegration and long run relationship, bound test is conducted on each model. The results are given in Table 3. The findings suggest that PS, CRP, and GE exhibit long run relationship with that of FAID. Therefore, it is justifiable to state that such governance indicators are not of cursory importance since FORAID is taken into account.

Table 3: Bound Test Results

\begin{tabular}{|c|c|c|c|c|}
\hline \multicolumn{5}{|c|}{ Model- I } \\
\hline Statistic & Value & Upper Bound Critical Value & Level of Significance & Conclusion \\
\hline F-statistic & 5.87 & 3.35 & $10 \%$ & Cointegration \\
\hline \multicolumn{5}{|c|}{ Model- I } \\
\hline Statistic & Value & Upper Bound Critical Value & Level of Significance & Conclusion \\
\hline F-statistic & 5.59 & 4.68 & $1 \%$ & Cointegration \\
\hline \multicolumn{5}{|c|}{ Model-III } \\
\hline Statistic & Value & Upper Bound Critical Value & Level of Significance & Conclusion \\
\hline F-statistic & 7.37 & 5.06 & $1 \%$ & Cointegration \\
\hline
\end{tabular}

After the confirmation of cointegration, long run and short run coefficients are explored. The results of long run coefficients are published in Table 4.

Table 4: Estimated Model-I to Model-III for Long Run Coefficient

\begin{tabular}{|c|c|c|c|c|c|c|c|c|c|c|c|}
\hline \multicolumn{4}{|c|}{ Model-I } & \multicolumn{4}{|c|}{ Model-II } & \multicolumn{4}{|c|}{ Model-III } \\
\hline Var. & Coeff. & S.E. & $t$ - Stat. & Var. & Coeff. & S.E. & $t$ - Stat. & Var. & Coeff. & $\overline{\text { S.E. }}$ & $t$ - Stat. \\
\hline $\mathrm{C}$ & 4.46 & 1.12 & $3.98 *$ & C & 516.86 & 197.86 & $2.61 *$ & $\mathrm{C}$ & -1.89 & 0.55 & $-3.44 *$ \\
\hline EGR & 0.00 & 0.00 & 1.41 & EGR & 0.01 & 0.00 & $2.54 *$ & EGR & 0.00 & 0.00 & 1.11 \\
\hline INF & -0.03 & 0.03 & -1.02 & CRP & -46.48 & 119.03 & -0.39 & INF & -0.03 & 0.03 & -0.83 \\
\hline UE & -0.55 & 0.19 & $-2.83 *$ & INF & 2.76 & 2.65 & 1.04 & UE & -0.79 & 0.25 & $-3.12 *$ \\
\hline PS & -0.91 & 0.34 & $-2.68 *$ & TR & -14.54 & 3.81 & $-3.81 *$ & $\mathrm{GE}$ & -7.51 & 2.20 & $-3.42 *$ \\
\hline M2 & -0.09 & 0.02 & $-4.31 *$ & UE & -17.78 & 4.38 & $-4.06^{*}$ & - & - & & - \\
\hline
\end{tabular}

* shows significant at 10 percent.

The governance indicators such as political stability, government effectiveness, and corruption have shown long run relationship with flow of foreign aid to Pakistan. Pakistan is among the countries those depend upon foreign aid for the survival of macroeconomic projects. Therefore, it is mandatory to look into the governance indicators for the uninterrupted flow of foreign aid. Table 4.4 represents EGR having unsubstantial effects on foreign aid. It is found insignificant on Model-I and Model-III. In reciprocation, Yiew and Lau (2018) also found no determination of economic growth at the back of foreign aid. It is therefore meaningful to note that no affectation of foreign aid and economic growth is evident in past studies. However, in exception to that, at Model-II, it is found significant and positive in effecting flow of foreign aid. It is due to trust of donors given the growing pattern of economy are traced.

INF is insignificant on entire models. It means that INF is nothing to concern with the flow of foreign aid to Pakistan. UE is found significant and negative in effecting foreign aid. At precise, a unit increase in UE is to bring up 0.55 and0.79 units of reduction in foreign aid. Economically, it can be justified that rise in unemployment shatters the demands of high salaries from the side of employees. Such expositions spell out to mark signals of hiring of labour at lower wage. Thus, becomes feasible for the state government to entertain the poverty alleviation and employment generation type of macroeconomic goals to be met without relying on tied-type foreign aid that brings perverse distortions in the two countries (Lahiri \& Raimondos-Møller, 1997). 
M2 and TR are found negative in effecting foreign aid. It means that increase in money supply can help government replacing foreign aid. Economically, it is justifiable. Since government needs are fulfilled by printing notes, there come no need to further borrow money from foreign sources, in shape of foreign aid. Therefore, money supply is a substitute of foreign aid. Moreover, increase in trade openness that helps make foreign exchange reserves healthy is also a praiseworthy activity which developing countries such as Pakistan can go for in order to reduce dependency on foreign aid.

Improvement in political stability and government effectiveness significantly reduce reliance on foreign aid. The findings suggest that better politics and effectiveness of government at internal and external fronts can further strengthen state and local government. This state of being at government and political level help in being self-sufficient and self-reliant.

Reciprocating the effects of foreign aid on political stability, Steinwand (2015) found the donors who are stability oriented also do efforts to keep risk of political conflicts away in the country they pledge their donations. Thereby, the political destabilization is reduced. To Boone (1996), foreign aid does not significantly contribute in reducing poverty by human development indicator. Neither improvement in investment is significantly traced. Therefore, findings of this study portrays that government effectiveness reduces the dependency on foreign aid because effective government tackles the internal issues by itself thus promising to contribute in addressing macroeconomic issues without any favours of foreign donors. Thus, in conclusion, due to political stability and better effectiveness of government, less becomes the need to rely on foreign capital in shape of foreign aid. The findings on control of corruption are however insignificant.

Short run results are rendered in Table 4.5. PS is found positive in effecting foreign aid at lag of one year. In case of GE, on significant results are found. At two year lag, CRP is computed to bring reduction in foreign aid. It means that better control on corruption also results in reducing dependency on foreign aid. Coefficient of error terms are found negative and significant on entire models. Thus, the divergence from state of equilibrium is found to get corrected in long run.

Conclusion is drawn on the facts of long run and short run coefficient estimates that; governance indicators are of much importance to the government in context of long run time period. Therefore, in case of short run, most of the observations on governance indicators are found insignificant.

Table 5: Estimated Model-I to Model-III for Short Run Coefficient

\begin{tabular}{|c|c|c|c|c|c|c|c|c|c|c|c|}
\hline & Model & & & & Model-I & & & & Model & & \\
\hline Var. & Coeff. & S.E. & $t$ - Stat. & Var. & Coeff. & S.E. & $t$-Stat & Var. & $\overline{\text { Coeff }}$ & S.E. & $t$-Stat. \\
\hline$d(E G R)$ & 0.00 & 0.00 & 1.40 & $d(E G R)$ & 0.01 & 0.00 & 0.08 & $\mathrm{~d}(\mathrm{EGR})$ & 0.00 & 0.00 & 0.41 \\
\hline $\mathrm{d}$ (INF) & -0.02 & 0.02 & -1.41 & d(CRP_) & -4.77 & 68.23 & 0.07 & $\mathrm{~d}(\operatorname{EGR}(-1))$ & 0.00 & 0.00 & 0.26 \\
\hline $\mathrm{d}(\mathrm{INF}(-1))$ & -0.02 & 0.01 & $-1.67 *$ & d(CRP_(-1)) & 129.03 & 96.21 & 0.34 & $d(I N F)$ & -0.02 & 0.02 & 0.85 \\
\hline $\mathrm{d}(\mathrm{UE})$ & -0.06 & 0.11 & -0.61 & $\mathrm{~d}\left(\mathrm{CRP}_{-}(-2)\right)$ & -131.41 & 73.04 & $1.80^{*}$ & $\mathrm{~d}(\mathrm{UE})$ & -0.12 & 0.13 & 0.88 \\
\hline$d(P S)$ & -0.33 & 0.40 & -0.83 & $d$ (INF) & 2.35 & 2.22 & 0.06 & $\mathrm{~d}(\mathrm{GE})$ & -0.41 & 0.88 & 0.46 \\
\hline $\mathrm{d}(\mathrm{PS}(-1))$ & 1.44 & 0.51 & $2.83^{*}$ & $\mathrm{~d}(\mathrm{TR})$ & -2.62 & 3.1 & 0.84 & CointEq(-1) & -0.56 & 0.13 & $4.47 *$ \\
\hline d(M2) & -0.06 & 0.01 & $-3.81 *$ & $\mathrm{~d}(\mathrm{UE})$ & -6.08 & 4.51 & 1.35 & - & . & - & - \\
\hline CointEq(-1) & -0.65 & 0.14 & $-4.67 *$ & $\mathrm{~d}(\mathrm{UE}(-1))$ & -1.24 & 5.45 & 0.23 & - & - & - & - \\
\hline- & & - & - & $\mathrm{d}(\mathrm{UE}(-2))$ & 7.99 & 4.88 & 0. & - & - & - & - \\
\hline - & - & - & - & CointEq(-1) & -0.85 & 0.16 & $5.24 *$ & - & - & - & _ \\
\hline
\end{tabular}

Note: $*$ show significant at 10 percent. 


\section{Conclusion and Policy Implications}

Foreign aid is indispensable for an economy and is considered as a virtuous tool to support the economic performance and stability at reducing poverty. Foreign aid is considered as a tool to capture the needs for capital for specifically developing countries. However, some of the governance issues can hinder the way of capturing benefits of foreign capital such as foreign aid. To do so, political stability, control of corruption, and government effectiveness were selected to distinguish their impacts on foreign aid. Cointegration was confirmed on each of governance indicator.

Most of the significant long run coefficients were found on political stability and government effectiveness. Coefficient of control of corruption was found to significantly affect foreign aid in short run. Moreover, other control variables also showed economically justified state of being against flow of foreign aid in both time horizons.

From the government's part, it is suggested to have a stronger and unaltered mechanism of presenting the country on external front in terms of such governance indicators so that the needs of capital be fulfilled in ready course of time and the foreign countries must not feel hesitant in remitting foreign aid.

\section{References}

Alvi, E. \& Senbeta, A. (2011). Does foreign aid reduce poverty? Journal of International Development, 24(8), 955-976.

Azam, A., Mehmood, K. A., Latif, N., Faridi, M. Z., \& Aurmaghan, M. (2020). Financial development and poverty mitigation: Evidence from Pakistan. International Journal of Management, 11, (8), 137-147.

Bacha, E. L. (1990). A three-gap model of foreign transfers and the GDP growth rate in developing countries. Journal of Development Economics, 32, 279-296.

Barro, R. J. \& Sala-i-Martin, X. (1997). Technological diffusion, convergence, and growth. Journal of Economic Growth, 2, 1-26.

Boone, P. (1996). Politics and the effectiveness of foreign aid. European Economic Review, 40(2), 289329.

Burnside, C. \& Dollar, D. (2000). Aid, policies, and growth. The American Economic Review, 90(4), 847868.

Chenery, H. B. \& Strout, A. M. (1966). Foreign assistance and economic development. The American Economic Review, 56(4), 679-733.

Dickey, D. A. \& Fuller, W. A. (1979). Distribution of the estimators for autoregressive time series with a unit root. Journal of the American Statistical Association, 74(366), 427-431.

Elbadawi, I. A. (1999). External aid: Help or hindrance to export orientation in Africa. Journal of African Economies, 8(4), 578-616.

Fafchamps, M. (2000). Ethnicity and credit in African manufacturing. Journal of Development Economics, 61(1), 205-235.

Friedman, M. (1958). Foreign aid. Yale Review, 47(4), 500-516.

Gomanee, K., Morrissey, O., Mosley, P. \& Verschoor, A. (2005). Aid, government expenditure, and aggregate welfare. World Development, 33(3), 355-370.

Hall, R. E. \& Jones, C. I. (1999). Why do come countries produce so much more output per worker than others? The Quarterly Journal of Economics, 114(1), 83-116.

Hjertholm, P. \& White, H. (2000). Survey of foreign aid: History, trends and allocation (Discussion Papers No. 4), Department of Economics, University of Copenhagen.

Kosack, S. \& Tobin, J. (2006). Funding self-sustaining development: The role of aid, FDI and government in economic success. International Organization, 60(1), 205-243.

Laffont, J. \& Guessan, T. N. (1999). Competition and corruption in an agency relationship. Journal of Development Economics, 60, 271-295. 
Lahiri S., Raimondos-Møller P. (1997) Tied Aid, Unemployment and Welfare. In: Borkakoti J., Milner C. (eds) International Trade and Labour Markets. Palgrave Macmillan, London. https://doi.org/10.1007/978-1-349-14577-5_10

Lake, D. A. (1999). Entangling relations: American foreign policy in its century. Princeton: Princeton University Press.

Lawson, M. L. \& Morgenstern, E. M. (2019). Foreign aid: An introduction to U.S. programs and policy. Congressional Research Services. Retrieved from: https://fas.org/sgp/crs/row/R40213.pdf

Levin, R. \& Renelt, D. (1992). A sensitivity analysis of cross-country growth regression. American Economic Review, 84(4), 942-963.

Maizel, A. \& Nissanke, M. K. (1984). Motivations for aid to developing countries. World Development, 912, 879-900.

Mehmood, K. A., Hassan, S. \& Faridi, M. Z. (2020). Do remittance outflow and exchange rate wavering distress domestic private investment in ASEAN? A conceptual panel cointegration. Journal of Contemporary Macroeconomic Issues, 1(1), 1-13.

Minoiu, C. \& Reddy, S. G. Development aid and economic growth: A positive long-run relation (IMF Working Paper No. 118). International Monetary Fund, Washington DC.

Minoiu, Camelia, Reddy \& Sanjay, (2010), Development aid and economic growth: A positive long-run relation. The Quarterly Review of Economics and Finance, 50(1), 27-39.

Mogenthau, H. (1962). The political theory of foreign aid. The American Political Science Review, 56(2), 301-309.

Nelson, T. (2010). Rejecting the gift horse: international politics of disaster aid refusal. Conflict, Security \& Development, 10(3), 379-402.

Pallage, S. \& Robe, M. A. (2015). Counterpart funds and the foreign aid Procyclicality Puzzle. Oxford Review of Economic Policy, 31(3-4), 462-480.

Pesaran, M. H., Shin, Y. \& Smith, R. J. (2001). Bound testing approaches to the analysis of level relationships. Journal of Applied Econometrics, 16(3), 289-326.

Rajan, R. \& Subramanian, A. (2008). Aid and growth: What does the cross-country evidence really show? Review of Economics and Statistics 90(4), 643-665.

Rawley, C. K. Political culture and economic performance in Sub-Saharan Africa (Working Paper, 1998). Department of Economics, George Mason University.

Steinwand, M. C. (2015). Foreign aid and political stability. Conflict Management and Peace Science, 32(4), 395-294.

Svensson, J. (2000). Foreign aid and rent-seeking. Journal of International Economics, 51, 437-461.

Weck-Hannemann, H. \& Scheider, F. (1988). Determinants of foreign aid under alternative institutional arrangements (Discussion Paper No. 66). Collaborative Research Centre, University of Konstanz.

Yiew, T. H., \& Lau, E. (2018). Does foreign aid contributes to or impeded economic growth. Journal of International Studies, 11(3), 21-30. 